\title{
CHARTER INTERPRETATION, JUDICIAL REVIEW AND A COMMUNITY'S CONSTITUTIONAL MORALITY: RESPONDING TO NATALIE STOLJAR ON WIL WALUCHOW*
}

INTERPRETACIÓN DE LA CARTA DE DERECHOS, REVISIÓN JUDICIAL Y LA MORAL CONSTITUCIONAL DE LA COMUNIDAD: RESPUESTA A NATALIE STOLJAR EN TORNO A WIL WALUCHOW

\author{
Maggie O'BRIEN**
}

\section{Resumen:}

En su artículo intitulado "Waluchow on Moral Opinions and Moral Commitments", Natalie Stolar presenta dos objeciones a la postura de W.J. Waluchow y su teoría del "common law" sobre la interpretación de cartas constitucionales. En mi artículo, intento proporcionar un resumen breve de la teoría de Waluchow sobre la interpretación de cartas constitucionales y responder a las críticas desarrolladas por Stoljar. Voy a denominar las críticas que presentar Stoljar como la "preocupación epistémica" y la "preocupación metodológica". Al discutir y atender estas preocupaciones, voy a concluir que existe una confusión de la teoria de Waluchow por parte de Stoljar. Principalmente, mi argumento es que existe un malentendido en lo que pretende conseguir Waluchow con su distinción entre "opiniones morales" y "compromisos morales". Asimismo, sostengo que Stoljar parte de ciertas suposiciones sobre la metodología de la teoría de Waluchow que son precipitadas. Al responder a Stoljar, espero esclarecer

* Artículo recibido el 17 de julio de 2014 y aceptado para su publicación el 10 de octubre de 2014.

** PhD student, McMaster University. Thanks to the participants of the 2014 Ontario Legal Philosophy Partnership Graduate Student Conference for their feedback on the paper. I would also like to thank Michael O'Brien, Katharina Stevens, and Wil Waluchow for their help and comments on earlier drafts. 
Este libro forma parte del acervo de la Biblioteca Jurídica Virtual del Instituto de Investigaciones Jurídicas de la UNAM

\title{
MAGGIE O'BRIEN
}

la teoría de Waluchow y aportar elementos para fortalecer su tesis de que podemos reconciliar el "judicial review" con la democracia.

\section{Palabras clave:}

Moral constitucional de la comunidad, interpretación de la Carta de derechos, revisión judicial, metodología de la filosofia del derecho, Wil Waluchow, Natalie Stoljar.

\begin{abstract}
:
In Natalie Stoljar's paper, 'Waluchow on Moral Opinions and Moral Commitments' she raises two objections to W.J. Waluchow's common law theory of charter interpretation. In this paper I aim both to provide a brief overview of Waluchow's theory of charter interpretation and to respond to the challenges advanced by Stoljar in her article. In my paper I have called the two main criticisms Stoljar presents the 'epistemic worry' and the 'methodological worry'. Discussing and addressing these worries, I believe, reveals a confusion on the part of Stoljar about Waluchow's theory. Namely, I argue that Stoljar misunderstands what Waluchow intends to accomplish in distinguishing between moral opinions and moral commitments. As well, I contend that she makes assumptions about the methodology involved in Waluchow's theory of charter interpretation that are precipitate and ultimately based on misunderstandings. In replying to Stoljar, I hope I have both clarified Waluchow's theory and, in doing so, added strength to his claim that we can reconcile judicial review with democracy.
\end{abstract}

\section{Keywords:}

Community Constitutional Morality, Charter Interpretation, Judicial Review, Jurisprudential Methodology, Wil Waluchow, Natalie Stoljar. 
CHARTER INTERPRETATION, JUDICIAL REVIEW AND CCM

SUMMARY: I. Introduction. II. Waluchow and his Community Constitutional Morality (CCM). III. Stoljar's Challenges to Waluchow. IV. Bibliography.

\section{INTRODUCTION}

In his book, A Common Law Theory of Judicial Review, W. J. Waluchow develops and defends a specific understanding of charters and bills of rights. ${ }^{1}$ Once we accept this understanding, Waluchow goes on to argue, we can defend judicial review from its most ardent objectors and in doing so reconcile the practice with democracy. In Natalie Stoljar's paper, 'Waluchow on Moral Opinions and Moral Commitments', she identifies two challenges to Waluchow's theory of charters and their interpretation. In what follows I aim to use the resources provided by Waluchow's writings on charters to respond to the criticisms raised by Stoljar. Ultimately, I argue that these worries rest on mistakes and misinterpretations. In highlighting these misunderstandings and responding to these errors I hope to both clarify and strengthen Waluchow's theory of charter interpre- tation.

To understand and appreciate Stoljar's criticisms it is important that the reader have at least a basic grasp of what Waluchow's theory puts forth. This is where I begin in the following section.

\section{Waluchow AND His COMmunity Constitutional MORALITY (CCM)}

A fundamental tenet of Waluchow's theory (and the object of one of Stoljar's criticisms) is the idea that we can (for the most part) accurately differentiate between mere moral opinions and moral commitments. Moral opinions tend to be knee-jerk reactions rather than well-considered and reflective moral commitments. Moral commitments are dis-

1 For reasons of convenience, I will henceforth refer simply to charters. 
tinct from mere moral opinions in that commitments are consistent, based on sincere beliefs, and in harmony with one's other judgments about specific cases. ${ }^{2}$ For example, someone with a green thumb may have the moral opinion that it is wrong for local government to impose restrictions on outdoor water use. Upon reflection, however, she would likely see that given her thoughts about the importance of recycling and composting, and her commitments to energy saving, her genuine moral commitment is actually in favour of limits on the use of water outdoors. Because moral opinions and moral commitments can conflict with one another a responsible moral agent ought to continuously reflect on her opinions and commitments and bring them in line with each other. A community is a moral agent and as such should maintain a consistent set of moral commitments. For Waluchow, one aspect of the role of judicial review is to help ensure this consistency for the community. He writes, 'why should judges deciding moral questions under a system of judicial review be required, for reasons of democracy, fairness and the like, to respect the moral opinions on the matter -as opposed to the community's true moral commitments...? Why should they bend to the community's inauthentic wishes, and not its authentic ones?'3

Waluchow argues that self-governance cannot be achieved if attempts at it are made based on inauthentic moral opinions. Therefore, when judges ignore the moral opinions of the community (its inauthentic wishes) in favour of the community's commitments they are not thwarting democracy because, as Stoljar acknowledges, '...moral opinions are inauthentic; they are not the preferences of agents acting autonomously'. ${ }^{4}$ To illustrate his point Waluchow

2 WJ Waluchow, 'Constitutional Morality and Bills of Rights' in Grant Huscroft (ed), Expounding the Constitution: Essays in Constitutional Theory (Cambridge University Press 2008) 72-73.

3 WJ Waluchow, A Common Law Theory of Judicial Review: The Living Tree (Cambridge University Press 2007) 225-226.

4 Ibid 104. 
uses the example of someone, let's call her Liz, who has too much to drink at the local watering hole. ${ }^{5}$ Liz's friends all know that she is vehemently opposed to drinking and driving as she has expressly said so on many occasions and has also volunteered with MADD. 6 Tonight, however, after having one too many, Liz drunkenly declares that she is perfectly capable of driving herself home. Waluchow contends that Liz's friends do not respect her autonomy by letting her drive because her desire to drive drunk is inauthentic insofar as it is fueled by gin. Rather, in order to respect Liz's autonomy her friends ought to prevent her from driving drunk and ensure that her actions remain consistent with her commitment to not drinking and driving. In this example, Liz's inauthentic wish is driven by alcohol, but inauthentic wishes and moral opinions can also be motivated by prejudice and hatred rooted in fear (especially fear of the unknown or different), inadequate evidence or information, or severe emotional hardship (for example, severe depression). Another useful example Waluchow utilizes to illustrate the difference between moral opinions and moral commitments is the decision to order the internment of Japanese Canadians during World War II. This decision was motivated by, 'fear of the unknown that led to deep suspicion against Japanese and those of Japanese decent'.7 This decision ran contrary to the community's commitments to equality and freedom of the person.

Given this distinction between inauthentic moral opinions and authentic moral commitments, Waluchow argues that judges and legislatures alike are more than justified in ignoring community's opinions when enacting legislation or deciding a charter case. In fact, when judges are ruling in charter cases they ought to rule in accordance with a community's constitutional morality. That is, they ought to rule according to community commitments that have found rec-

5 I have changed the example slightly, but the basic idea is the same.

6 Mothers Against Drunk Driving.

7 Waluchow (n3) 100. 
ognition within the law through legislation, past judicial decisions, and/or constitutions or charters. 8

An example that Waluchow discusses is the Canadian legalization of same-sex marriages. Prior to its legalization same-sex marriage ran contrary to the popular sentiments of Canadians. ${ }^{9}$ However, as Waluchow repeatedly stresses, the genuine commitments of a community are not revealed through simple opinion polls. Constitutions, judicial decisions, and legal precedents are key parts of a community's constitutional morality and are furthermore, evidence of the community's genuine moral commitments. Thus in deciding the same-sex marriage case the judges in an attempt to rule in accordance with the community's constitutional morality would have looked to past judicial rulings, such as those that gave spousal benefits to same-sex couples, to constitutional commitments to equality, and to legal commitments that oppose sexism, racism, and the oppression of minority groups. These factors would have revealed that in fact CCM required the legalization of same-sex marriage. What is more, although the decision that a failure to recognize the validity of same-sex marriage was unconstitutional went against popular moral opinion, the judges who decided the case in fact ruled according to the community's genuine commitments and, in doing so, respected the autonomy of the citizens and upheld democracy. They did this in the same way that Liz's friends respected her autonomy when they prevented her from drinking and driving in the example looked at earlier.

8 Waluchow (n2) 27; Waluchow (n3).

9 Many Canadian courts ruled that the opposite-sex requirement of civil marriage was inconsistent with the equality clause of S.15 in the Charter. For example, the Ontario Court of Appeal in Halpern v. Canada (Attorney General) [2003] O.J. No. 2268 and the Supreme Court in the Reference re Same-Sex Marriage [2004] 3 SCR 698. In the Reference case the Federal government requested the opinion of the Supreme Court on whether or not the common law definition of marriage (as applying only to opposite-sex couples) violated the Charter. 


\section{StOlJAR's Challenges to Waluchow}

With an idea of what Waluchow argues for in hand, we are now in a better position to look at the challenges Stoljar raises. Stoljar describes two difficulties she sees in Waluchow's theory. First, she thinks that what Waluchow has described as an epistemic failing is actually a moral failing. I shall refer to this as the 'epistemic worry'. Secondly, Stoljar contends that there is a tension between the way Waluchow characterizes the methodology required to identify CCM and the actual methodology necessary to do so. That is, she does not think that CCM can be identified using the methodology Waluchow describes. I call this the 'methodological worry'. The epistemic worry is potentially the most devastating to Waluchow's theory because it threatens to undermine the democratic nature of CCM. The resources within his theory, however, are I believe, more than able to respond to it. It is with this worry that I begin.

\section{The Epistemic Worry}

Waluchow does a lot of work to show that judicial review can be reconciled with democracy by arguing that judges who rule according to commitments rather than opinions respect the autonomy of the community. ${ }^{10} \mathrm{He}$ also maintains that his position does not commit him to either a substantive or majoritarian understanding of democracy. ${ }^{11}$ This is an advantage of his theory because it avoids some of the standard criticisms of charters and judicial review. ${ }^{12}$ As previously discussed Waluchow argues that in order to respect a moral agent's autonomy we need to hold them ac-

10 In fact, he goes on to suggest that judicial review may be a necessary feature of a democratic society. See Waluchow (n2) 92.

11 This will be important later on because what Stoljar suggests would commit him to a substantive understanding of democracy.

12 See, for example, Jeremy Waldron, 'A Rights-Based Critique of Constitutional Rights' (1993) 13 Oxford Journal of Legal Studies 18 and Jeremy Waldron, Law and Disagreement (Oxford University Press 1999). 
countable to their genuine commitments —as Liz's friends did. The examples Waluchow uses to help illustrate the difference between opinions and commitments seem to imply, as Stoljar rightly notices, that there are epistemic conditions that need to be met for a belief to count as a moral commitment. ${ }^{13}$ As Stoljar writes, "The commitment that one should not drink and drive satisfies the test. It is formulated by a rational, informed, clear-headed agent. On the other hand, the desire to drive while drunk is formulated by an agent whose mind is clouded by alcohol'. ${ }^{14}$ Liz's declaration that she can drive herself home is an opinion indicative of an epistemic failing (one caused by an over indulgence in gin and tonics). Stoljar, however, goes on to argue that some of the examples Waluchow uses seem to be examples of moral failings rather than epistemic ones. What is more, Stoljar contends that moral failings are not indicative of a mere moral opinion. That is, someone can be genuinely committed to a prejudicial belief. For example, the prejudicial attitudes that were largely behind Canada's internment of the Japanese during WW2 were more likely a moral failing than an epistemic one. Prejudice may be a moral failing but it is possible for persons to authentically adopt and sincerely endorse seriously problematic moral beliefs. What is more, because these bigoted beliefs are genuine commitments, respecting them is consistent and necessary for respecting the autonomy of the individuals who hold them. That is, we cannot claim that when we ignore the prejudiced but nevertheless genuine racist commitments of the $\mathrm{Ku}$ Klux Klan that we have in fact respected their autonomy in doing so. This means that when judges disregard prejudicial community beliefs, such as those of a community made up of white supremacists, they are undermining the principle of self- governance, a fundamental tenet of democ-

13 Natalie Stoljar, 'Waluchow on Moral Opinions and Moral Commitments' (2009) 3 Problema Anuario de Filosofía y Teoría del Derecho 101, 122 .

14 Ibid 122. 
racy. Waluchow has to accept that prejudicial opinions are moral failings and as such are authentic. He cannot claim that, 'opinions with certain moral contents-namely that members of minorities have lesser or insignificant moral worth - are judged to be inauthentic'. ${ }^{15}$

In identifying this problem Stoljar is not aiming to show that Waluchow's theory of charter interpretation cannot be as democratic as Waluchow wants it to be, but rather she endeavors to show that the process cannot be as descriptive as he wants it to be -it must become a normative test. She writes, '... if Waluchow's test of authenticity is to do the work it is required to do - namely, classify preferences denying rights to minorities as inauthentic- it must be construed as a moral test. The distinction between inauthentic moral opinions and authentic moral commitments is a moral distinction'.16 Waluchow would want to resist the claim that distinguishing between inauthentic moral opinions and authentic moral commitments is a moral distinction because that would amount to judges invalidating laws based on their own moral reasoning rather than their assessment of the community's moral commitments. Additionally, endorsing the moral distinction would, as Stoljar notes, also commit Waluchow to a substantive conception of democracy which makes his theory more vulnerable to criticisms. As well, accepting Stoljar's claim would also commit Waluchow to the view that laws of apartheid South Africa were not representative of their genuine commitments something he clearly denies. ${ }^{17}$ Thus, I think in order to respond to Stoljar's epistemic worry in a manner Waluchow would approve of we need to demonstrate how the resources within $\mathrm{CCM}$ can deal with authentic prejudicial community moral commitments. I think there are at least two responses available to Waluchow.

15 Ibid 127.

16 Ibid 128.

17 Ibid 128. 


\section{Responding to the Epistemic Worry}

In distinguishing between epistemic failings and moral failings Stoljar treats them as though they are completely separable failings, but I think she is wrong to do so. Some moral failings including some prejudices are based on epistemic failings and in these cases the prejudices are not really authentic. For example, imagine a father who refuses to give his daughter skittles because he believes that skittles turn girls into psychopaths, but happily gives them to his son (because he will not turn into a skittle-fueled psychopath). On the face of it the decision to deny the girl the skittles but give them out to the son seems like one rooted in prejudice and sexism, - just another example of the ubiquitous pattern of having one rule for girls and another for boys-. That is to say, that it is a moral failing on behalf of the father. We can just as easily imagine, however, that if we showed the father empirical evidence that convinced him that skittles do not turn girls in psychopaths he would more than happily give up his belief that he ought not give his daughter skittles. In this case, at first blush it is not easy to decide whether the father was guilty of a moral or epistemic failing, but I think it is clear that his belief was not authentic. Thus, Stoljar is wrong to treat epistemic failings and moral failings as wholly separable and distinct. Furthermore, because moral failings and epistemic failings can be bound up together she is wrong to assume that moral failings are necessarily authentic. Sometimes, as was the case with our father, the moral failing can be corrected when the epistemic failing is corrected.

Some may argue that the example I have provided is too simplistic to actually be argumentatively useful. People hold views that are prejudicial and more complicated than my, fictional skittle-denying father and these views cannot be refuted simply by descriptive analysis. Thus, we are forced to accept Stoljar's claim that we need to bring in normative analysis in order to be able to reject these views. I do not think, however, that this is always the case. People, 
generally speaking, want to be considered reasonable and as such they often provide reasons that they think other people can understand and relate to. That is, they attempt to provide non-idiosyncratic reasons to back up their idiosyncratic beliefs. For example, the view that we should avoid doing things that make our children sick is not idiosyncratic, but the view that we should not give girls skittles is. What is more, we have real world examples of this.

Let us look to the work of Loretta Kopleman on female genital mutilation (FGM). In her paper, 'Female Circumcision/Genital Mutilation and Ethical Relativism,' Kopleman argues that we can analyze the rightness or wrongness of FGM by looking to the reasons that people offer in favour of the practice. That is, because, for example, we (as people cross-culturally and globally) share standards of scientific evidence and methodology, we can critically examine the 'scientific' reasons offered in support of the practice. In the end, Kopleman finds multiple contradictions and conflicts between the reasons provided in support of FGM and the actual facts of FGM. I survey two of these conflicts.

One reason offered in favour of FGM is that the practice fulfills a religious requirement. The majority of women who have FGM performed on them are Muslim; however, the practice is not required by the Koran. Additionally, FGM is not practiced in Saudi Arabi - the religious centre of Islam-. Furthermore, Kopleman notes that FGM predates Islam, which, she argues, strongly suggests that FGM is not a core aspect of Islamic beliefs, but is part of a pagan superstition that Islam was meant to replace. ${ }^{18}$ Kopleman contends that these empirical observations give us reason to reject the claim that FGM fulfills a religious requirement and thus it can no longer count as a reason in favour of the practice.

A second reason provided to support FGM is that the practice helps maintain female health and cleanliness.

18 Loretta Kopleman, 'Female Circumcision/Genital Mutilation and Ethical Relativism' (1994) 20 Second Opinion 54, 60. 
There is, however, no medical evidence to support this claim. In fact, FGM has been linked to serious health problems such as shock, infertility, infections, incontinence, maternal-fetal complications, and protracted labour. ${ }^{19}$ The medical evidence not only undermines the claim that the practice is healthy but it demonstrates the complete opposite -FGM causes significant harm to the girls and women it is performed on, both immediately after the procedure and in their adult lives-.

Supporting the practice of female genital mutilation is a moral failing, but those who support it attempt to give reasons based in facts. We can engage with and critically assess these reasons. The moral failing is based on epistemic failings (according to Kopleman) and ideally when these epistemic failings are pointed out people will give up their moral failing.

It is, of course, not guaranteed that when the epistemic failings are corrected that people will also correct the corresponding moral opinion. They may cite a reason that is difficult or impossible to analyze logically (for example, supporters of FGM often claim that the practice helps maintain group identity) or they may just flatly refuse to give up their prejudicial views. ${ }^{20}$ It seems here we are left with the original problem that Stoljar identified - some moral failings are authentic and no amount of empirical information is going to uproot those prejudicial beliefs from the minds of those who endorse them. Does Waluchow's theory account for this fact and does it provide the resources to respond? The short answer is yes.

Waluchow is certainly aware that some people and some communities are deeply committed to morally reprehensible

19 Ibid 60.

20 Kopleman (n18) 60.

Group identity is, I think, more difficult to analyze than say the purported medical benefits of FGM. It is still reasonable, however, I believe to engage with this reason by asking questions about how much of the group identity is rooted in this practice and what would be lost if the practice was given up. 
opinions. But we must remember that Waluchow is working with three different types of morality ${ }^{1}$ - moral opinions, moral commitments, and a community's constitutional morality. A judge, according to Waluchow, is obliged to rule according to a community's constitutional morality not according to its moral opinions or even its moral commitments. Remember - a community's constitutional morality is tied to the law and is composed of moral commitments that have found recognition in the law through, for example, judicial decisions or legislation. What is more, Waluchow, explicitly acknowledges that his discussion of judicial review and charter interpretation is only applicable to, 'contemporary constitutional democracies [...] [that] thoroughly reject any opinion that oppresses a minority group, harbors the prejudices of patriarchy, and so on'.22 This means that a group of KKK members who are thoroughly committed to bigotry and racism, but who live in a liberal democracy will have their commitments ignored by the judiciary. This is because the KKK's commitments are irreconcilable with equality. In noting that the racist views of the KKK are in contradiction with the American Constitution's commitment to equality a judge is not making a moral judgment, but simply describing a reality.

Responding to Stoljar's epistemic worry reinforces the importance of being clear about what Waluchow is trying to accomplish in his discussion of moral opinions and moral commitments. Stoljar seems to think that, in making the distinction, Waluchow wants to be able to 'classify preferences denying rights to minorities as inauthentic'23 and thus the distinction between the two is a moral one. But this is a mistake. The distinction is meant to do just what Waluchow says - distinguish between knee-jerk reactions and well-considered commitments. Certainly, the hope is

21 A fact to which Stoljar brings our attention, but seems to forget later in her paper. See Stoljar (n13) 110.

22 Waluchow (n2) 89.

23 Stoljar (n13) 128. 
that the distinction will catch moral failings, but it will not always do so. Nor is it the purpose of the distinction to do so. For example, the distinction enables us to say that the view that black and white people should not marry each other is a sincere commitment of a member of the KKK. In Waluchow's view, prejudice does not make the belief inauthentic; rather it is what can motivate inauthentic beliefs. If we return to the example of Canada's internment of Japanese Canadians in WW2 I think the role of the distinction will become clearer. Stoljar thinks that this example illustrates her claim that the distinction is a moral one because the interment is a clear example of a moral failing. But to think this way is to misunderstand the example. The internment of the Japanese Canadians was motivated by fear and prejudice, but this is not what made the decision inauthentic or a moral opinion. What did do so was the fact that the decision ran contrary to Canada's constitutional commitments to equality and freedom of the person.

The responses I have presented to the epistemic worry both resists Stoljar's normative move and is in agreement with Waluchow's claim that apartheid South Africa and Nazi Germany had, as Stoljar writes, 'morally repugnant'24 constitutional moralities. That is to say, that community commitments of these countries to hatred and prejudice had found recognition in law and would be what judges in their role as judges should have ruled according to. 25 Waluchow is committed to acknowledging that both Nazi Germany and apartheid South Africa had authentic constitutional moralities albeit morally repugnant ones. The move that Stoljar advocates, however, would commit us to the

24 Ibid 126.

25 When I say 'should' I do not mean in the morally normative sense. I only mean to say that a judge in those countries looking to the CCM would find it bigoted and prejudicial and the laws similarly such. Whether or not the judges in these countries should have applied the law of the time is a separate question to what $\mathrm{CCM}$ required at the time. For a thoughtful discussion of judicial deviation see Brand Ballard's, Limits of Legality: The Ethics of Lawless Judging (Oxford University Press 2010). 
claim that neither apartheid South Africa nor Nazi Germany had authentic constitutional moralities because her moral test would dictate that their hateful and prejudicial views were inauthentic and would therefore not be part of their CCM. ${ }^{26}$

\section{The Methodological Worry}

The second worry that Stoljar presents is that of a tension between the methodology described by Waluchow in his writings on CCM and the actual methodology required to access CCM. She claims that Waluchow endorses a 'descriptive' methodology, but that what is actually required is a 'constructive' methodology. ${ }^{27}$ The descriptive methodology 'claims that interpreters must attempt to describe a community's actually held values and principles...'.28 On the other hand, in the constructive methodology 'interpreters are adopting a normative and justificatory methodology [...] They theorize about what the community would or should believe, often employing some set of idealized conditions...'.29 In an effort to motivate her claim that CCM actually requires a constructive methodology, Stoljar draws on Waluchow's reliance on Hart and Hart's theory of legal vagueness and application in unforeseen cases. ${ }^{30}$ On that view, she claims, whenever there is linguistic vagueness in the law there is a gap in existing law and the judge has to create new law. For example, because the term 'equality' is vague, the judge may have to create law that determines what equality requires for purposes of law. This means that the judges are not discovering what equality actually requires (and thus not using a descriptive methodology), but rather they are deciding and

26 Stoljar (n13) 126.

27 Waluchow does not take on either a descriptive or constructive label for the methodology needed to interpret CCM. These are Stoljar's terms.

28 Ibid 115, my emphasis.

29 Ibid 116.

30 Ibid 119. 
constructing what equality requires. This leads Stoljar to the conclusion that Walu- chow's methodology is constructive not descriptive.

Stoljar also argues that because of the unavoidable linguistic vagueness of the law in many cases, judges will be required to weigh competing principles and that this also implies a constructive method. ${ }^{31}$ She draws on the Canadian case of Charkaoui' 32 'concerning legislation whose aim was to promote national security, which in effect allowed the indefinite detention of non-citizens who were suspected of terrorist activity'. ${ }^{3}$ This case required judges to weigh principles upholding national security against those protecting the right to life, liberty and security of the person. The Supreme Court of Canada ruled unanimously in favour of the latter. For an advocate of the descriptive method, Stoljar claims, this example seems to demonstrate that the Court identified the genuine requirements of CCM. The same advocate would, however, also have to admit that the legislature's position in this case is inauthentic, a mere moral opinion. She seems to think that this is not a plausible position. ${ }^{34}$ Given this she contends that the case better exemplifies the constructive approach: it makes precise a substantive aspect of constitutional morality, namely the scope and weight of the constitutional right to life, liberty, and security of the person in national security contexts'. ${ }^{35}$ Thus she argues that the model of constitutional interpretation endorsed by Waluchow is best understood as utilizing a constructive methodology, rather than a descriptive one.

31 Ibid 120.

32 Charkaoui v. Canada (Citizenship and Immigration), 2007 SCC 9 (The Security Certificates Case).

33 Stoljar (n13) 120.

34 She asks 'Is this a plausible position?' Stoljar doesn't answer her own rhetorical question, but it seems her answer is no. She does not, however, provide an argument for this answer. See Stoljar (n13) 120.

35 Stoljar (n13) 120. 
In the next section I aim to respond to the claims described above. Ultimately, I will argue that Stoljar's worry is based on a confusion. She is wrong to suggest that the descriptive methodology and the constructive methodology are competing forms of interpretation or that we have to choose one or the other. Rather, I think, the descriptive methodology is best understood as a part of, or even a step in, the constructive methodology. To begin, however, I want to add some force to the descriptive methodology as described by Soljar. That is, I want to show that the descriptive methodology can do more work in deciding charter cases than Stoljar seems to appreciate.

\section{Responding to the Methodological Worry}

Stoljar contends that the Charkaoui case is best understood as having been decided using the constructive methodology. It is not entirely clear why she thinks this, but it seems to have something to do with the fact that the case required weighing of principles and that using the descriptive method commits one to seeing the legislature's position on the issue before the courts as a mere moral opinion (which she seems to think is implausible). To begin, weighing principles does not necessarily require the constructive method. Remember, according to the descriptive method, judges are not weighing the principles according to their own subjective morality, but are making good faith decisions about how the community, given its constitutional commitments, has weighed the principles. Secondly, the claim that the legislature's position was inauthentic or a mere moral opinion seems perfectly plausible. The circumstances of rule making make it more than plausible that the enacted legislation and thus the legislature's opinion is indeed a mere moral opinion rather than a moral commitment. ${ }^{36}$ The legislature is elected by the majority and as such it is likely to make decisions according to popular ma-

36 Waluchow (n3); (n2). 
jority opinion instead of engaging in serious and thoughtful reflection and deciding what the community's moral commitments actually are. The Charkaoui case involved fears of terrorism and worries about national security. Fear was likely motivating the majority of people to support the legislation in question. That is, the popular opinion was in favour of heightened national security laws and the legislature responded accordingly. The Charkaoui case does not speak in favour of the constructive methodology over the descriptive one.

Stoljar's strongest argument for the constructive methodology relies on the linguistic vagueness of the law. For the descriptive methodology to be successful it needs to describe what the CCM surrounding equality actually requires. For example, what does the community's constitutional commitment to equality actually say in regard to same-sex marriage? On the other hand, the methodology cannot be descriptive if judges are creating law where before there had been none. But because vague terms are indeterminate, judges will, the argument goes, be obliged to create law. However, we can accept that a term is vague over time, but maintain that at a specific point in time it may be quite clear what that term requires. Let us look to another case to show that the descriptive methodology can work. In the fourth chapter of his book, The Living Constitution, David Strauss, aims to show how we can understand the decision in Brown v. The Board Education ${ }^{37}$ as both lawful and in line with the rulings that came before it. In sketching the legal history that led up to the decision in Brown, Strauss illustrates a large part of what Waluchow has in mind for judges to be doing in attempting to decide what CCM requires. Strauss claims that the rulings before Brown thad already left 'separate but equal' in shambles'. 38 Given this, 'Brown was the completion of an evolutionary, common law

37347 U.S. 483 (1954).

38 David Strauss, The Living Constitution (Oxford University Press 2010) 85. 
process, not an isolated, pathbreaking act'. ${ }^{39}$ If Strauss is right, the Brown case can be best understood using the descriptive methodology. I summarize some of the cases Strauss discusses that make up the 'evolutionary, common law process' of Brown. One such case is that of Missouri ex. rel Gaines $v$. Canada. ${ }^{40}$ In this case an African-American student was denied admission to the University of Missouri Law School which was all-white at the time. To appease African-American students, Missouri law authorized state officials to arrange transportation so that black students could attend law schools in nearby states and the state of Missouri would pay for their tuition. The court ruled that this offer did not satisfy 'separate but equal' - having to go out of state, even to a good school, did not satisfy the 'equal' part of 'separate but equal'. 41

Another notable case Strauss discusses is Sweatt $v$. Painter. ${ }^{42}$ The central question in this case was whether or not a separate law school that Texas had established for African-American students was equal to the University of Texas Law School. The Court ruled that it was not. It identified concrete differences between the two schools, but as Strauss highlights, the court also explicitly drew on intangible differences between the schools: 'those qualities which are incapable of objective measurement but which make for greatness in a law school'. ${ }^{43}$ While 'separate but equal' was technically still the law up until the decision in Brown, the Courts before had time and time again ruled that separate facilities were in fact not equal. There was nothing left of 'separate but equal' by the time Brown came before the court, and thus Brown merely made the already developed interpretation of the law and the community's constitutional morality explicit.

39 Ibid 85.

402305 U.S. 337 (1938).

41 Strauss (n39) 87-88.

42339 U.S. 629 (1950).

43 Strauss (n39) 98. 
The Brown example nicely illustrates how a descriptive methodology can determine the actual requirements of CCM. Imagine Warren, when Brown came before him, as attempting to decide what $\mathrm{CCM}$ required. Given that at the time the Brown decision was controversial and met with outrage, it seems as if the community's opinion was in favour of the racial segregation of students in schools. The community's commitments, however, were different and were revealed through the rulings in the cases that came before and in the past legislation that had chipped away at separate but equal. The Texas decision which had made reference to certain intangible aspects of schools made it clear that separate could not be interpreted in a way that could be reconciled with the community's constitutional commitments to equality. The legal and legislative history along with the American constitution's commitment to equality seem to make it clear that the community's commitments were actually against racial segregation. Thus, Warren's decision, though it went against widespread popular opinion, was in fact both lawful and democratic. By outlawing 'separate but equal' Warren gave the community no choice but to recognize their own genuine commitments. Brown demonstrates that while equality is an indeterminate term over time what it requires of a community at a specific time can be quite determinate, a fact that can be determined descriptively.

As noted earlier, Stoljar makes an error when she suggests that we must choose to endorse either the descriptive methodology or the constructive methodology. Part of my argument rests on understanding the difference between the two methodologies. The distinction between the two that Stoljar seems to stress is that the descriptive methodology asserts that interpreters attempt to describe 'actually held values and principles'44 whereas the constructive methodology demands that interpreters 'theorize about

44 Stoljar (n13) 115. 
what the community would or should believe'. 45 But this distinction does not really clarify what she means by distinguishing these two theories of interpretation. We must understand what she means by 'would or should believe'. Does the constructive methodology require that interpreters ask what the community 'would or should believe' if they were good moral people or what they 'would or should believe' if all their beliefs were consistent with each other? Stoljar adds to her distinction that the constructive methodology often employs a set of idealized conditions. But are these idealized conditions ones where the community has perfect answers to moral questions or conditions where the community is consistent in its beliefs? The constructive methodology that Waluchow would endorse would answer in favour of consistency. That is, the appropriate methodology asks judges to interpret what the community is committed to, given the community's constitutional commitments; not what the community would be committed to if they were perfectly good people. It is worth stressing that a judge interpreting the CCM of apartheid South Africa would have to find it racist. The judge could not interpret the CCM of apartheid South Africa such that it no longer reflected its racist laws. Given that the appropriate understanding of the constructive methodology requires judges to interpret $\mathrm{CCM}$ from the perspective of the community I hope it has become clear why the methodology required to interpret CCM is both descriptive and constructive.

It may be helpful to think of the descriptive methodology as 'evidence gathering' and the constructive methodology as interpreting the evidence and deciding what it means in regards to the specific case in front of the judge. The descriptive methodology requires judges to look at the moral commitments that have found recognition within the law through judicial decisions, legislation, and constitutions. The constructive methodology asks judges to interpret the evidence as it applies to the current case. So that we may

45 Ibid 116. 
see this more clearly, it may be helpful to return to the Charkaoui case. Stoljar is certainly right to assert that the Charkaoui case required judges to weigh principles upholding national security against those protecting the right to life, liberty and security of the person. But the judges, if we understand them as interpreting CCM, weighed the principles, not according to their own morality, but according to community's constitutional commitments that were revealed during what I have called the 'evidence gathering' stage. That is, previous legislative and judicial decisions and Charter commitments indicated that Canada was committed to upholding freedom of the person over national security.

It should now be clear that admitting that the methodology required in deciding charter cases is constructive is not to throw out descriptive methodology altogether. Interpreting CCM will involve both methodologies. There will be some cases where the legal history or evidence does more work to indicate what CCM requires, as in the case of same-sex marriage, and others where the legal history is not as definitive, as perhaps in the case of abortion. In the latter case the judge may recognize that the legal history does not lead to a specific answer - just answers. But the judge will decide from among these answers from the perspective of the community using 'public reasons' which are also part of the CCM. ${ }^{46}$

46 In a previous article Waluchow suggests that the case of the abortion may be an example where CCM runs out because in some cases 'arising under CCM, especially those in which passions and controversy run deepest, and where differences are rooted in significantly different comprehensive doctrines, there is no uniquely correct answer to be found just answers'. See W.J. Waluchow, 'On the Neutrality of Charter Reasoning' in J. Beltran et al. (eds) Neutrality and Theory of Law (Springer 2013) 209 supra note 16 . In these cases he suggests that judges ought to rely on 'public reasons' to make decisions. However, I think he is wrong to admit that CCM runs out because the 'public reasons' that Waluchow suggests judges use are actually a part of CCM. Given recent personal discussion with Waluchow it seems that he agrees that CCM may not run out. Thus, I 
Stoljar's worries about Waluchow's theory of interpretation are, I contend, based on misunderstandings. She is wrong to suggest that moral failings and epistemic failings are completely distinct and wrong to claim that, in making the distinction between moral commitments and moral opinions, Waluchow has committed himself to a substantive moral standard. Furthermore, she is wrong to assume that the constructive methodology and the descriptive methodology are rival theories of interpretation. The de- scriptive methodology is better understood as an important part of the constructive methodology - it is part of what roots the interpretation of $\mathrm{CCM}$ in a specific community. In responding to Stoljar I hope I have clarified Waluchow's theory strength to his claim that we can reconcile judicial review with democracy.

\section{BIBLIOGRAPHY}

Ballard Brand, Limits of Legality: The Ethics of Lawless Judging (University Press 2010).

Kopleman Loretta, "Female Circumcision/Genital Mutilation and Ethical Relativism" (1994) 20 Second Opinion 2.

Stoljar Natalie, "Waluchow on Moral Opinions and Moral Commitments" (2009) 3 Problema. Anuario de Filosofía y Teoría del Derecho 101.

think a better way to understand cases where 'passions and controversy run deepest' are cases where the legal history is less definitive and judges need to rely more on public reasons. A discussion of Waluchow's account of what public reasons are is beyond the scope of my paper. Roughly, however, we can understand 'public reasons' as reasons which the general public can find acceptable. This rules out deciding cases based on a coin flip, or on the basis of which lawyer bribed the judge with the most money, as well as reasons rooted in the private sphere such as religious doctrine. For a description of his account and arguments in favour of it see Waluchow's chapter 'On the Neutrality of Charter Reasoning' in J. Beltran et al. (eds) Neutrality and Theory of Law. What public reasons are and how they interact with what I've called the 'legal pattern or legal history' needs further work. 
Strauss David, 'Brown v. Board of Education and Innovation in the Living Constitution (with a Note on Roe v. Wade)' in his The Living Constitution (Oxford University Press 2010).

Waldron Jeremy, "A Rights-Based Critique of Constitutional Rights" (1993) 13 Oxford Journal of Legal Studies 1.

- Law and Disagreement (Oxford University Press 1999).

Waluchow Wil, A Common Law Theory of Judicial Review: The Living Tree (Cambridge University Press 2007).

'Constitutional Morality and Bills of Rights' in Grant Huscroft (ed), Expounding the Constitution: Essays in Constitutional Theory (Cambridge University Press 2008).

'On The Neutrality of Charter Reasoning' in Jordi Ferrer Beltrán and others (eds), Neutrality and Theory of Law (Springer 2013).

Halpern v. Canada (Attorney General) [2003] O.J. No. 2268.

Supreme Court in the Reference re Same-Sex Marriage [2004] 3 SCR 698.

Charkaoui $v$. Canada (Citizenship and Immigration), 2007 SCC 9 (The Security Certificates Case).

347 U.S. 483 (1954).

2305 U.S. 337 (1938).

339 U.S. 629 (1950). 
Este libro forma parte del acervo de la Biblioteca Jurídica Virtual del Instituto de Investigaciones Jurídicas de la UNAM www.juridicas.unam.mx

http://biblio.juridicas.unam.mx 